\title{
Differential Expressions of Selected Activating and Inhibitory Receptors on K562-Stimulated Natural Killer (NK) Cells in HIV-1 and HIV-2 Infections
}

\author{
Samuel V. Nuvor ${ }^{1,2^{*}}$, Sarah Rowland-Jones ${ }^{1,3}$, Hilton Whittle ${ }^{1,4}$, Assan Jaye , $^{1,5}$ \\ ${ }^{1}$ MRC Laboratories, Fajara, Banjul, The Gambia \\ ${ }^{2}$ School of Medical Sciences, University of Cape Coast, Cape Coast, Ghana \\ ${ }^{3}$ MRC Human Immunology Unit, Weatherall Institute of Molecular Medicine, John Radcliffe Hospital, Oxford, \\ UK \\ ${ }^{4}$ London School of Hygiene \& Tropical Medicine, London, UK \\ ${ }^{5}$ Hopital A. Le Dantec, Laboratoire de Bacteriologie Virologie (LBV), Universite Cheikh Anta Diop (UCAD), Dakar, \\ Senegal \\ Email: s.v.nuvor@uccsms.edu.gh
}

Received 14 February 2015; accepted 4 March 2015; published 10 March 2015

Copyright (C) 2015 by authors and Scientific Research Publishing Inc.

This work is licensed under the Creative Commons Attribution International License (CC BY).

http://creativecommons.org/licenses/by/4.0/

(c) (i) Open Access

\section{Abstract}

Context: The functional activity of NK cells depends on the balance between the engagement of activating and inhibitory receptors on the cell surface with their ligands, which enables them to kill infected cells. Objectives: The aim of this study was to evaluate and compare expressions of selected activating and inhibitory receptors on stimulated NK cells in HIV-1 and HIV-2 infections. Methods: PBMCs were analysed for activating (NKp30, NKp44, NKp46) and inhibitory (CD158a, CD158b, p70) receptor expressions in 30 HIV-1, 30 HIV-2 and 30 HIV uninfected healthy control (HC) subjects by flow cytometry after stimulating with K562 cells. Results: There was an expression of other receptors following an already in vitro engagement of NK cells with K562 cells. Higher expression of the activating receptors, NKp44 $(p=0.029)$ and $N K p 46(p=0.032)$ on $N K$ cells from HIV-2 compared to HIV-1 infected individuals but similar NKp30 expression ( $p=0.980)$. The levels of expression of inhibitory receptor CD158a were similar between HIV-1 and HIV-2 infected subjects $(p=0.309)$ but there was significant up-regulation of inhibitory receptors $p 70(p=$ $0.010)$ and CD158b (p = 0.05) in HIV-1 compared to HIV-2 subjects. Conclusion: Despite the in vitro engagement of NK cells with stimulating K562 cells, our data showed differential expressions of other selected activating and inhibitory receptors in HIV-1 and HIV-2 infected subjects.

\footnotetext{
${ }^{*}$ Corresponding author.
}

How to cite this paper: Nuvor, S.V., Rowland-Jones, S., Whittle, H. and Jaye, A. (2015) Differential Expressions of Selected Activating and Inhibitory Receptors on K562-Stimulated Natural Killer (NK) Cells in HIV-1 and HIV-2 Infections. World Journal of AIDS, 5, 21-29. http://dx.doi.org/10.4236/wja.2015.51003 
Keywords

NK Cells, HIV-1, HIV-2, IFN- $\gamma$, CD4 T Cells

\section{Introduction}

The mechanisms underlying the long-term non-progression observed in many subjects with HIV-2 infection are yet to be elucidated and could be attributed to viral factors [1], host immune factor and/or the ability of the viruses to induce an effective immune response [2]. Comparative adaptive immune response studies have suggested better qualitative response in HIV-2 infection than HIV-1 asymptomatic infections [3] [4]. We have shown that effector NK cells, which are one of the key components of the innate immune response, have enhanced function in asymptomatic HIV-2 compared to HIV-1 individuals [5]. This may contribute to an effective immune response which results in prolonged stable $\mathrm{CD}^{+} \mathrm{T}$ cell counts and a healthy state. Activated natural killer cells provide the first line of defence in the early stage of viral diseases including HIV infection [6] and function by secretion of antiviral soluble factors or kill infected cells. Though natural killer cells are not MHCrestricted, its functions are mediated through the binding of a pattern of receptors specific for MHC Class I molecules and other unidentified ligands. The binding of these receptors can transmits inhibitory signals to NK cells, thus making them non-functional. The inhibitory receptors are not engaged during down-regulation of MHC or altered MHC Class I expression as observed during HIV infection [7], permitting the activation of NK cells and subsequent lysis of their target cells. Such cytolysis is mediated through the perforin, granzyme B or Fas lytic pathway [8], or by antibody-dependent cell cytotoxicity through CD16 receptors expressed on NK cells [9]. The difficulty in demonstrating in vitro NK lysis of autologous naturally HIV-infected targets [10] has made it possible to use NK-sensitive cell lines such as erythroleukemia cells (K562) [6] [11]. However, subsequent works have employed techniques that showed lysis of primary CD4 T cells by NK cells [12] [13].

The receptor engagement mechanism for sustainable effector functions of NK cells is complex and it is not known to what extent there are simultaneous expressions of activating and inhibitory receptors during an ex vivo activated NK cell function. The commonly reported activating natural cytotoxicity receptors (NCRs) include NKp30, NKp44, NKp46 and NKG2D [14]. NKG2D, NKp 30 and NKp46 are expressed on resting NK cells as well as $\mathrm{T}$ cells, and their blockage impairs target cells lysis by NK cells [15]-[17]. Until recently their ligands were unknown although it had been suggested that NKp30 and NKp46 interacted with dendritic cells and haemagglutinin, respectively [18] [19]. NKp44 is expressed when NK cells are activated and may enhance killing of targets cells [20]. This is done through ligands that are expressed on HIV infected CD4 T cells and their expression is found to be highly correlated with CD4 T cell decline and increased viral load [21].

There are equally different groups of inhibitory receptors, killer-cell immunoglobulin like receptors (KIR) with different numbers of immunoglobulin-like domains [22], such as CD158a (KIR2DLI), CD158b (KIR2DL2) p70 (KIR3DL1) and CD158k, which recognise different alleles of HLA-A, B and C molecules. The ability of these receptors to bind to HLA molecules on the surface of the HIV infected cells may down regulate the the cytolytic function of NK cells.

We previously showed an increase in NK cell activity in asymptomatic HIV-2 infected compared to HIV-1 infected individuals when ex vivo NK cells were stimulated with K562 cells [5]. For this reason, we postulate that the in vitro engagement of stimulating K562 with target NK cells will retain expressions of other activating and inhibitory receptors and there will be differential expressions on the activated NK cells between the two infections.

\section{Methods}

\subsection{The Study Subjects and Blood Samples}

Subjects were recruited from a cohort of HIV infected individuals who attend clinic at the MRC Laboratories in Fajara, the Gambia [23].

Because the most significant functional differences between the two infections in NK cells activity occurred in asymptomatic individuals in our previous study [5], we recruited $30 \mathrm{HIV}-1$ and $30 \mathrm{HIV}-2$ subjects with high 
CD4-T cell count (>500 cells/ $\mu \mathrm{L}$ ) who were anti-retroviral therapy (ART) naïve clinically, proven to be free from cases of tuberculosis or any other disease condition. As were expected the HIV-1 subjects had significantly higher mean plasma viral load (Table 1). Thirty HIV-negative healthy subjects recruited from the Royal Victoria Teaching Hospital Blood Bank, Banjul, The Gambia were also studied. Peripheral blood mononuclear cells (PBMCs) were derived from $15 \mathrm{ml}$ of blood from these individuals by high density Ficoll separation technique. Samples were taken after obtaining a signed consent forms of the subjects according to the regulation of Gambia Ethical Committee.

\subsection{Determination of NK Receptor Expressions by Flow Cytometry}

Peripheral Blood Mononuclear Cells were stained in 96-well plates and incubated with $5 \times 10^{3} \mathrm{~K} 562$ cells at an E:T ratio of 50:1 with complete R-10 medium and IL-2 as described previously [24]. Our previous study also support the use of 50:1 E:T ratio as appropriate in carrying cytolytic activity of NK cells in PBMCs using K562 cell lines (8). Negative controls were PBMCs with medium alone. To test other putative receptor expressions during NK cells engagement with target cells, the following antibodies NKp30, NKp44, and NKp46 (R\&D systems, UK), CD158a, CD158b and p70 (Beckman Coulter, UK) were used. CD3 and CD56 (BD Biosciences, UK) were also included in the staining panel. The cells were acquired by FACScalibur using Cell Quest Pro software until 300,000 events were collected. There subsequently analysed by FCS Express Software (De novo software).

\subsection{Statistical Analysis}

Statistical analysis was done using Graphpad prism and $\mathrm{p}<0.05$ was used as significant level. The levels of upregulation or down-regulation of activating and inhibitory receptors on NK cells were analysed in HIV-1 and HIV-2 infected subjects compared with HIV uninfected controls using the unpaired Student t-test, Mann Whitney $\mathrm{U}$ test and Kruskal-Wallis test. Data are presented as the mean with standard error.

\section{Results}

\subsection{NK Cell Subsets and Expression of Activating and Inhibitory Receptors}

A dot plot of subsets of NK cells represented by CD56 $6^{\text {dim }}$ and CD56 $6^{\text {bright }}$ cells analysed from samples obtained from study subjects is shown in Figure 1(a) using a four-coloured FAScalibur flow cytometry. The expression of activating and inhibitory receptors on NK cells is also shown from the gated population of the CD56 bright and $\mathrm{CD}^{\mathrm{dim}}{ }^{\mathrm{dim}}$ cells. The level of receptor expressions was determined by the differences between cultured PBMCs alone and PBMCs stimulated with K562 cells (Figure 1(b)). Mostly receptor expression levels were seen to be up-regulated in test samples with K562 cells compared to control samples but in some cases they were downregulated.

Besides exclusive expression of activating or inhibitory receptors by NK cell subsets, smaller number of them expressed both activating and inhibitory receptors (Figure 1(b)). The expressions of both activating and inhibitory receptors from the NK CD56 ${ }^{\mathrm{dim}}$ cells (Table 2) showed significant lower expression of both NKp30/CD158 receptors in HIV-1 $(-0.95 \pm 0.75)$ compared to HIV uninfected individuals $(0.82 \pm 0.39), p=0.033$, but similar to HIV-2 infected subjects $(0.36 \pm 0.39)$. The combined expressions of other activating and inhibitory receptors in both CD56 $^{\text {dim }}$ and CD56 ${ }^{\text {bright }}$ NK cells were similar in HIV-1, HIV-2 and HIV uninfected individuals, p > 0.05 .

Table 1. The characteristics of HIV infected patients and healthy control.

\begin{tabular}{|c|c|c|c|c|c|c|c|c|}
\hline \multirow[b]{2}{*}{ Groups } & \multicolumn{8}{|c|}{ Characteristic and HIV status } \\
\hline & $\begin{array}{c}\text { CD4 } \\
\text { counts/ } \mu \mathrm{L}\end{array}$ & $\mathrm{n}$ & Male & Female & $\begin{array}{c}\text { Age } \\
\text { mean } \pm \mathrm{SE}\end{array}$ & $\begin{array}{c}\mathrm{CD} 4 \% \\
\text { mean } \pm \mathrm{SE}\end{array}$ & $\begin{array}{c}\mathrm{CD} 8 \% \\
\text { mean } \pm \mathrm{SE}\end{array}$ & $\begin{array}{l}\text { Viral load } \\
\text { (log) }\end{array}$ \\
\hline HIV-1 & $>500$ & 30 & 10 & 20 & $30.25 \pm 1.46$ & $28.58 \pm 1.14$ & $41.47 \pm 2.12$ & $4.3 \pm 0.1^{*}$ \\
\hline HIV-2 & $>500$ & 30 & 7 & 23 & $39.69 \pm 2.44$ & $33.80 \pm 1.62$ & $37.87 \pm 2.08$ & $3.21 \pm 0.1^{*}$ \\
\hline Healthy control & - & 30 & 16 & 14 & $33.02 \pm 1.25$ & $37.12 \pm 0.99$ & $26.80 \pm 3.13$ & - \\
\hline
\end{tabular}

*The viral load is significantly higher in HIV-1 compare to HIV-2 p $<0.0001$. 


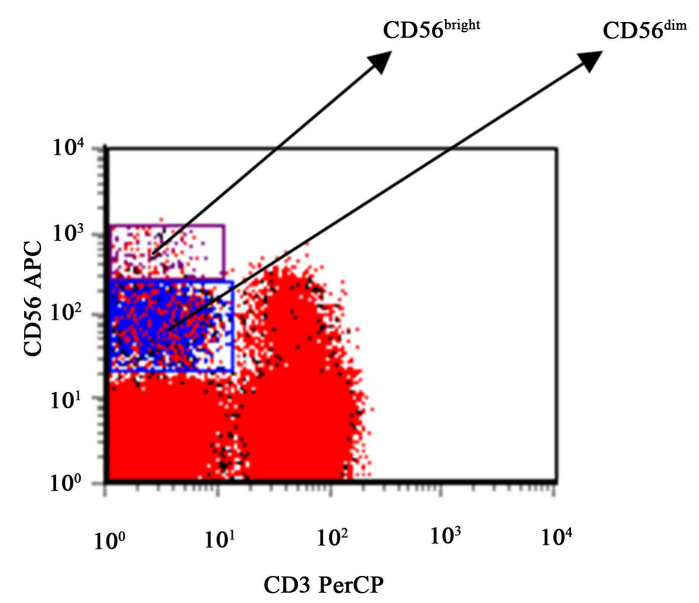

(a)

Control

CD56 $^{\text {dim }}$ cells

CD158aPE

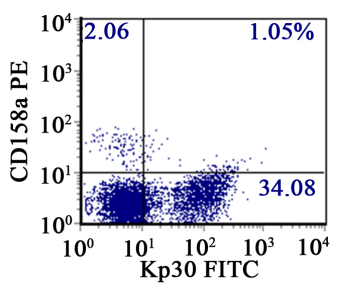

\section{CD158b PE}
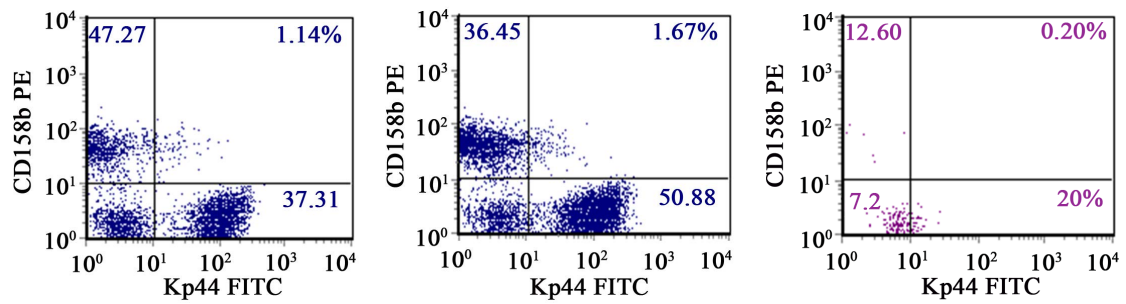

NKp44 FITC

P70PE
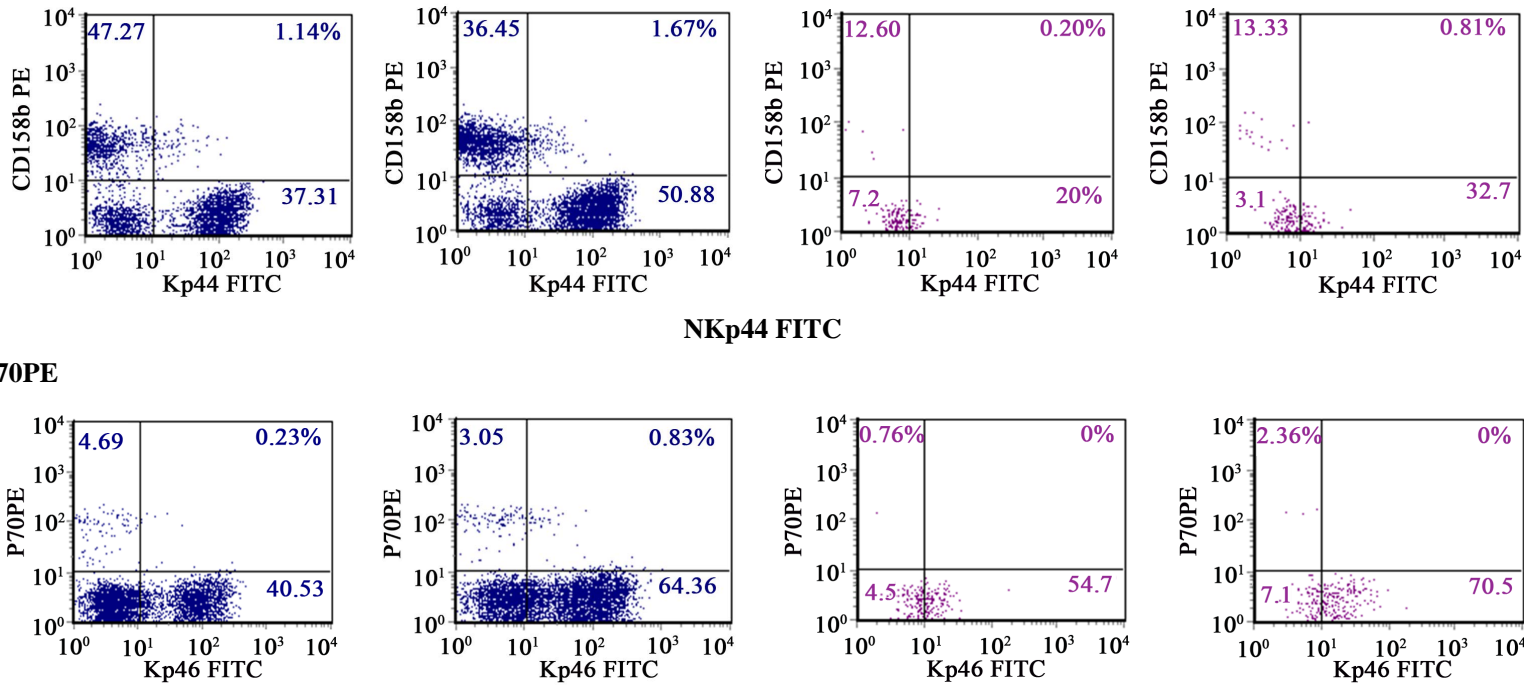

\section{NKp46FITC}

(b)

Figure 1. (a) A combined surface marker staining for NK CD56 $6^{\text {dim }}$ and CD56 $6^{\text {bright }}$ subsets. For each subject, PBMCs alone and PBMCs plus K562 cells at a ratio of 50:1 were incubated overnight in 96-well plate at $37^{\circ} \mathrm{C}$; (b) Natural killer cell receptors. NKp30, NKp44, NKp46 and killer cell Immunoglobulin-like (KIR, inhibitory) Receptors, CD158a (KIR2DL1), CD158b (KIR2DL2) and p70 (KIR3DL1) expression on the surface of CD56 ${ }^{\text {dim }}$ and CD56 $6^{\text {bright }}$ NK cells. PBMCs from HIV-1 and HIV-2 infected subjects and HIV uninfected controls were cultured alone (control) and stimulated with K562 cells overnight. Events of 300000 were acquired by flow cytometry and CD56 $6^{\mathrm{dim}}$ and CD56 $6^{\text {bright }}$ cells were gated and analysed. 
Table 2. The percentage of natural cytotoxity and killer cell immunglobulin-like (KIR, inhibitory) receptor expression on CD56 ${ }^{\text {dim }}$ and CD56 ${ }^{\text {bright }}$ NK cells.

\begin{tabular}{ccccc}
\hline & & \multicolumn{2}{c}{ HIV status } \\
\hline NK cells & Activating/inhibitory receptors & $\begin{array}{c}\text { HIV-1\% } \\
\text { mean } \pm \text { SE }\end{array}$ & $\begin{array}{c}\text { HIV-2\% } \\
\text { mean } \pm \text { SE }\end{array}$ & $\begin{array}{c}\text { HIV-ve\% } \\
\text { mean } \pm \text { SE }\end{array}$ \\
\hline & NKp30/CD158a (KIR2DL1) & $-0.95 \pm 0.75^{*}$ & $0.36 \pm 0.39$ & $0.82 \pm 0.39^{*}$ \\
CD56 ${ }^{\text {dim }}$ & NKp44/CD158b (KIR2DL2) & $0.18 \pm 0.37$ & $0.16 \pm 0.19$ & $0.24 \pm 0.19$ \\
& NKp46/P70 (KIR3DL1) & $1.08 \pm 0.69$ & $0.82 \pm 0.29$ & $1.41 \pm 0.51$ \\
\hline NKp30/CD158a (KIR2DL1) & $2.41 \pm 2.68$ & $0.80 \pm 1.15$ & $0.42 \pm 0.30$ \\
& NKp44/CD158b (KIR2DL2) & $4.07 \pm 2.38$ & $0.26 \pm 0.13$ & $0.17 \pm 0.16$ \\
\hline
\end{tabular}

${ }^{*} \mathrm{p}=0.033$.

\subsection{Natural Cytotoxicity Receptor Expression on CD56 dim and CD56 bright NK Cells}

The levels of expression of natural cytoxicity receptors by both subsets of NK cells were analysed. In the NK CD56 ${ }^{\mathrm{dim}}$ population, the up-regulation of the NKp30, NKp44 and NKp46 receptors was found to be similar between HIV-1 and HIV-2 subjects and in the healthy controls (Figures 2(a)-(c)). The comparison of the expressions of these receptors by NK CD56 bright cells however, showed that NKp44 expression was significantly up-regulated in HIV-2 infected subjects $(10.2 \% \pm 4.3 \%)$ compared to HIV-1 infected subjects $(-0.5 \% \pm 1.9 \%)$, $\mathrm{p}=0.029$ (Figure 3(b)) and HIV uninfected controls $(-1.5 \% \pm 3.0 \%), \mathrm{p}=0.027$. The expression of NKp44 was down-regulated in HIV-1 and HIV uninfected controls, $\mathrm{p}=0.79$. The NKp46 receptors were also significantly up-regulated in HIV-2 infected subjects $(17.9 \% \pm 6.0 \%)$ compared to HIV-1 infected subjects $(-0.2 \% \pm 5.5 \%) \mathrm{p}$ $=0.032$ (Figure 3(c)) and were not different from HIV uninfected controls $(8.7 \% \pm 2.5 \%), p=0.129$.

\subsection{The Inhibitory Receptor Expression by NK Subsets}

Although there are several inhibitory receptors on NK cells our choice of receptors was base on some of the most common inhibitory receptors expressions in relation to HIV infection [25]. The expression of inhibitory receptors was generally down-regulated in CD56 ${ }^{\mathrm{dim}}$ NK cells (Figures 4(a)-(c)). The CD158a (KIR3DLI) expression was similar in HIV-1 $(-0.2 \% \pm 0.9 \%)$ and HIV-2 $(-1.9 \% \pm 0.9 \%), \mathrm{p}=0.77$, infected subjects and similar to that of HIV uninfected controls $(-1.2 \% \pm 0.7 \%), p>0.05$. The expression of CD158b (KIR2DL2) NK CD56 ${ }^{\text {dim }}$ cells on the other hand was significantly higher in HIV-1 infected subjects $(0.5 \% \pm 1.9 \%)$ compared to HIV-2 infected subjects $(-4.5 \% \pm 1.7 \%), p=0.05$ whereas the down-regulation of CD158b (KIR2DL2) receptors in HIV-2 infected subjects was similar to HIV uninfected controls $(-4.4 \% \pm 1.9 \%), \mathrm{p}=0.07$. The NK CD56 ${ }^{\text {dim }}$ cells also showed down-regulation of p70 (KIR3DL1) in both HIV-1 $(-1.7 \% \pm 1.0 \%)$ and HIV-2 $(-1.01 \% \pm$ $0.5 \%)$ infected subjects, $\mathrm{p}=0.51$, that was again similar to HIV uninfected controls $(-1.09 \% \pm 0.6 \%), \mathrm{p}>0.05$.

The expression of inhibitory receptors p70 (KIR3DL1) by CD56 $6^{\text {bright }} \mathrm{NK}$ cells was significantly up-regulated in HIV-1 infected subjects $(1.6 \% \pm 0.6 \%)$ compared to HIV-2 infected subjects $(-0.3 \% \pm 0.4 \%) \mathrm{p}=0.010$ and in HIV uninfected controls $(-0.4 \% \pm 0.3 \%), p=0.003$. The expression in HIV-2 infected subjects was similar to that of HIV uninfected controls, $\mathrm{p}=0.82$, (Figure $5(\mathrm{c})$ ). However, there was no difference between the expression of CD158a (KIR2DL1) by CD56 $6^{\text {bright }}$ cells between HIV-1 $(0.6 \% \pm 0.8 \%)$ and HIV-2 infected subjects $(-0.6 \% \pm 1.0 \%) \mathrm{p}=0.31$; which was also similar in HIV uninfected controls $(-3.7 \% \pm 2.3 \%) \mathrm{p}=0.10$ (Figure 5(a)). Again, CD56 ${ }^{\text {bright }}$ NK cells showed similar levels of CD158b (KIR2DL2) between HIV-1 $(0.1 \% \pm 0.7 \%)$, HIV-2 $(-0.04 \% \pm 0.6 \%) \mathrm{p}=0.84$ and HIV uninfected controls $(0.03 \% \pm 0.4 \%) \mathrm{p}=0.86$ (Figure 5(b)).

In summary, the key findings were that expression of NKp44 and NKp46 receptors on NK cells were significantly up-regulated in HIV-2 compared to HIV-1 infected subjects after stimulating with K562 cell lines. This corresponded with significant down-regulation of inhibitory receptors, p70 and CD158b. These findings may support the effective functional activity of NK cells noted in our previous study [5]. 


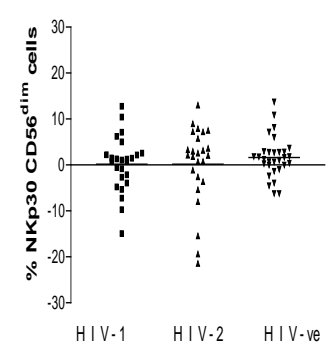

(a)

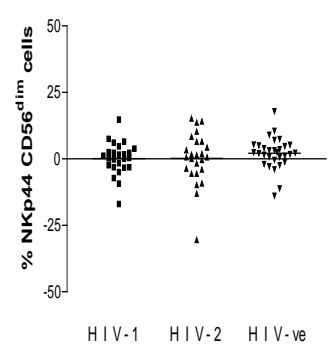

(b)

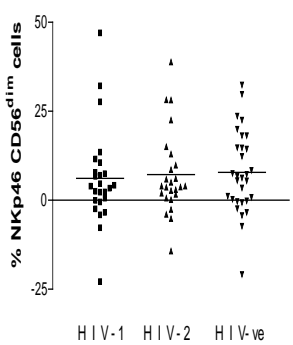

(c)

Figure 2. Natural cytotoxity receptors on CD56 $6^{\mathrm{dim}}$ NK cells. The expression of (a) NKp30 (b) NKp44 and (c) NKp46 on the surface of CD56 ${ }^{\text {dim }}$ NK cells stimulated with K562 cells overnight in 30 HIV-1, 30 HIV-2 and $30 \mathrm{HIV}$ uninfected controls. Data is presented as mean and standard deviation.

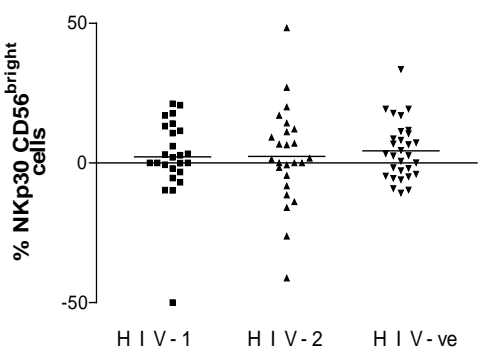

(a)

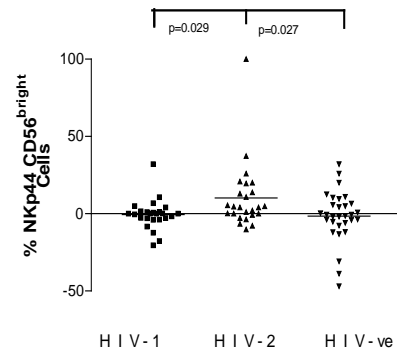

(b)

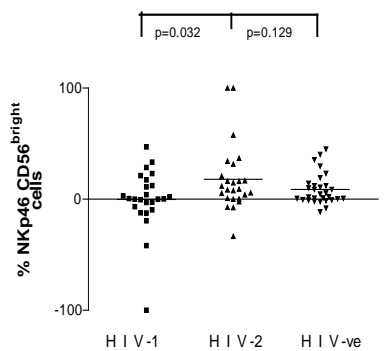

(c)

Figure 3. Natural cytotoxity receptors on CD56 ${ }^{\text {bright }}$ NK cells. The expression of (a) NKp30 (b) NKp44 and (c) NKp46 on the surface of CD56 $6^{\text {bright }}$ NK cells stimulated with K562 cells overnight in 30 HIV-1, 30 HIV-2 and $30 \mathrm{HIV}$ uninfected controls. Data is presented as mean and standard deviation and p-value if significantly compared are shown.

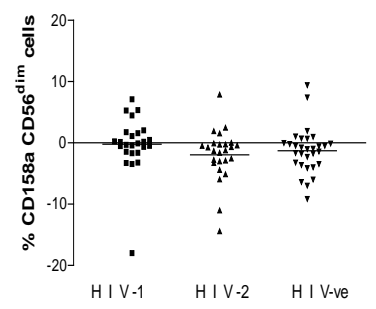

(a)

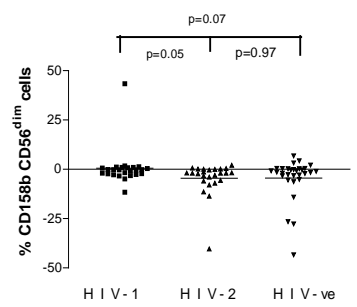

(b)

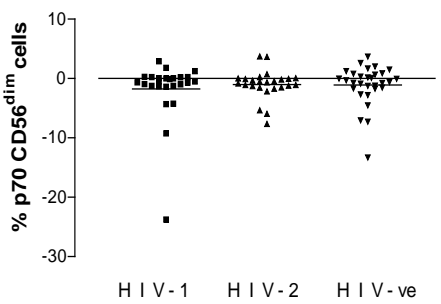

(c)

Figure 4. Immunglobulin-like (KIR, inhibitory) receptors on CD56 ${ }^{\mathrm{dim}}$ NK cells. The expression of killer (a) CD158a (KIR2DL1) (b) CD158b (KIR2DL2) and (c) p70 (KIR3DL1) on the surface of CD56 dim NK cells stimulated with K562 cells overnight in 30 HIV-1, 30 HIV-2 and 30 HIV uninfected controls. Data is presented as mean and standard deviation.

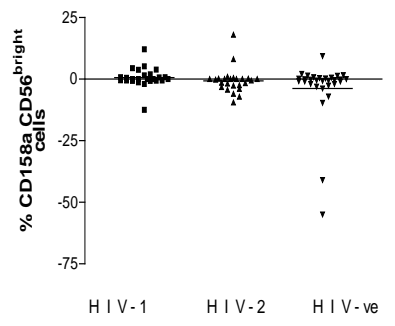

(a)

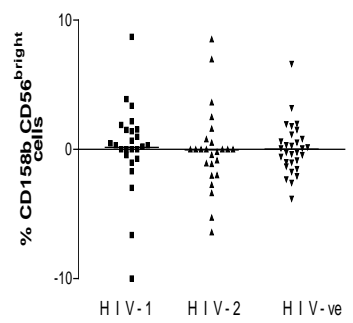

(b)

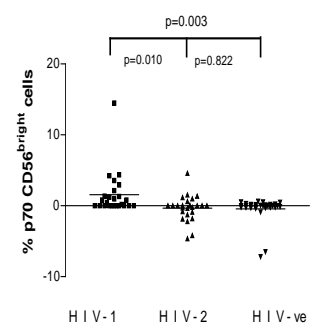

(c)

Figure 5. Killer cell immunglobulin-like (KIR, inhibitory) receptors on CD56 ${ }^{\text {bright }}$ NK cells. The expression of (a) CD158a (KIR2DL1) (b) CD158b (KIR2DL2) and (c) p70 (KIR3DL1) on the surface of CD56 ${ }^{\text {bright }}$ NK cells stimulated with K562 cells overnight in $30 \mathrm{HIV}-1,30 \mathrm{HIV}-2$ and $30 \mathrm{HIV}$ uninfected controls. Data is presented as mean and standard deviation and significant p-values are shown. 


\section{Discussion}

The ability of NK cells to recognise and lyse infected cells and produce effector cytokines depend on the expression levels of both activating and inhibitory receptors on their surfaces. The regulation of some MHC Class I molecules on the surface of the infected cells also contributes to the cytolytic activity of NK cells. The initial ligation of NK cells to infected cells would trigger an effector function if inhibitory receptors were unable to bind to their MHC Class I ligands. In a number of viral infections including HIV some types of MHC Class I molecules are down-regulated and thus protect infected cells from NK cells lysis [26]. Following on from our observation that HIV-2 asymptomatic subjects exert more efficient NK cellular activity than was noted in HIV-1 infected subjects at the same stage of the disease, it was hypothesized that there would be differential levels of activating and inhibitory receptor expressions on NK cells in the two infections. Our results therefore showed higher expression of the natural cytotoxic receptors (NCR) NKp44 and NKp46 by NK cells from HIV-2 compared to HIV-1 infected subjects but that of NKp30 receptors was similar. NKp30 and NKp46 are usually expressed on both resting and activating NK cells, with NKp44 expressed only on activated cells and their surface density has been found to correlate with the magnitude of NK cells cytolytic activity [27]. The expression of NCRs in HIV-2 than in HIV-1 may contribute a lot in maintaining or prolonging asymptomatic condition by enhancing NK cells activity. The differential levels of expression of these activating receptors in the two infections suggest that the type of infection may influence the levels of NK activity.

There are many receptors and co-receptors that play a role in NK cell functions. Our studies of receptors in relation to NK cell function in HIV infection were limited because of the restricted availability of reagents. We noted some differences in the levels of expression of inhibitory receptors evaluated. Interestingly, there were two specific inhibitory receptors that were up-regulated in HIV-1 and not in HIV-2 infected subjects. High levels of expression of CD158b and p70 inhibitory receptors in CD56 ${ }^{\text {dim }}$ and CD56 $6^{\text {bright }}$ NK cells in HIV-1 infected subjects respectively may suggest that these are virus-specific effects. The expression of inhibitory receptors has been found to relate directly to high levels of HIV-1 viremia [28]-[30] and may in turn lead to lower cytolytic activity by NK cells. The mechanisms by which the virus is able to circumvent the immune function of the host are not entirely clear but evasion of the host immune system leads to the malfunction and depletion of NK cells. However, our observation that inhibitory receptors expression is higher in HIV-1 infection is consistent with our data that NK cell activity is more effective in asymptomatic HIV-2 infection than in HIV-1 [5], further highlighting the importance of innate immune responses in the control of HIV infection.

Although we were not able to determine the HLA types of the study subjects, the high levels of p70 and $\mathrm{CD} 158 \mathrm{~b}$ on NK cells in HIV-1 subjects may suggest a possible protection against rapid disease progression if majority of them belongs to HLA-Bw480I types [25]. However, higher expression of KIR3DS1 in HIV-2 subjects in a data by Yindom et al. [31] could contribute to longer period of non-disease progression. It is therefore likely the symptomatic condition of the HIV-1 subjects may be due to high levels of p70 and CD158b which may be temporary and eventually lead to disease progression.

\section{Conclusion}

The levels of expression of activating and inhibitory receptors on NK cells are different between HIV-1 and HIV-2 asymptomatic subjects and the higher levels of functional activity by NK cells from HIV-2 subjects in our previous study may be a reflection of higher expression of NK activating receptors and lower levels of inhibitory receptors in this infection.

\section{Acknowledgements}

We do appreciate the contribution of Bakary Sanneh, Mamadi Njie, Abdoulai Jabang at the HIV Category 111 laboratory. Thanks to Sarah Crozier for assisting in statistical analysis of the data. We also thank Tumani Corrah, the Director of MRC Unit in the Gambia for his support. This work was supported by MRC Quinquenniel funding to the MRC Unit, The Gambia. We also thank the HIV Trust Fund, UK for sponsoring VN for work attachment in the USA.

\section{References}

[1] Pantaleo, G. and Fauci, A.S. (1996) Immunopathogenesis of HIV Infection. Annual Review of Microbiology, 50, 825- 
854. http://dx.doi.org/10.1146/annurev.micro.50.1.825

[2] Harrer, T., Harrer, E., Kalams, S.A., Elbeik, T., Staprans, S.I., Feinberg, M.B., et al. (1996) Strong Cytotoxic T Cell and Weak Neutralizing Antibody Responses in a Subset of Persons with Stable Nonprogressing HIV Type 1 Infection. AIDS Research and Human Retroviruses, 12, 585-592. http://dx.doi.org/10.1089/aid.1996.12.585

[3] Duvall, M.G., Jaye, A., Dong, T., Brenchley, J.M., Alabi, A.S., Jeffries, D.J., et al.(2006) Maintenance of HIV-Specific CD4 ${ }^{+}$T Cell Help Distinguishes HIV-2 from HIV-1 Infection. Journal of Immunology, 176, 6973-6981. http://dx.doi.org/10.4049/jimmunol.176.11.6973

[4] Gillespie, G.M., Stewart-Jones, G., Rengasamy, J., Beattie, T., Bwayo, J.J., Plummer, F.A., et al. (2006) Strong TCR Conservation and Altered T Cell Cross-Reactivity Characterize a B*57-Restricted Immune Response in HIV-1 Infection. Journal of Immunology, 177, 3893-3902. http://dx.doi.org/10.4049/jimmunol.177.6.3893

[5] Nuvor, S.V., van der Sande, M., Rowland-Jones, S., Whittle, H. and Jaye, A. (2006) Natural Killer Cell Function Is Well Preserved in Asymptomatic Human Immunodeficiency Virus Type 2 (HIV-2) Infection but Similar to That of HIV-1 Infection When CD4 T-Cell Counts Fall. Journal of Virology, 80, 2529-2538. http://dx.doi.org/10.1128/JVI.80.5.2529-2538.2006

[6] Kottilil, S., Chun, T.W., Moir, S., Liu, S., McLaughlin, M., Hallahan, C.W., et al. (2003) Innate Immunity in Human Immunodeficiency Virus Infection: Effect of Viremia on Natural Killer Cell Function. Journal of Infectious Diseases, 187, 1038-1045. http://dx.doi.org/10.1086/368222

[7] Hultstrom, A.L., Bratt, G., Cosma, A., Erfle, V., Wahren, B. and Carbone, E. (2004) Autologous Cytotoxicity of Natural Killer Cells Derived from HIV-Infected Patients. Immunology Letters, 91, 155-158. http://dx.doi.org/10.1016/j.imlet.2003.11.012

[8] Lowin, B., Hahne, M., Mattmann, C. and Tschopp, J. (1994) Cytolytic T-Cell Cytotoxicity Is Mediated through Perforin and Fas Lytic Pathways. Nature, 370, 650-652. http://dx.doi.org/10.1038/370650a0

[9] Ahmad, R., Sindhu, S.T., Toma, E., Morisset, R., Vincelette, J., Menezes, J., et al. (2001) Evidence for a Correlation between Antibody-Dependent Cellular Cytotoxicity-Mediating Anti-HIV-1 Antibodies and Prognostic Predictors of HIV Infection. Journal of Clinical Immunology, 21, 227-233. http://dx.doi.org/10.1023/A:1011087132180

[10] Bonaparte, M.I. and Barker, E. (2003) Inability of Natural Killer Cells to Destroy Autologous HIV-Infected T Lymphocytes. AIDS, 17, 487-494. http://dx.doi.org/10.1097/00002030-200303070-00003

[11] Scott-Algara, D., Truong, L.X., Versmisse, P., David, A., Luong, T.T., Nguyen, N.V., et al. (2003) Cutting Edge: Increased NK Cell Activity in HIV-1-Exposed but Uninfected Vietnamese Intravascular Drug Users. The Journal of Immunology, 171, 5663-5667. http://dx.doi.org/10.4049/jimmunol.171.11.5663

[12] Fogli, M., Mavilio, D., Brunetta, E., Varchetta, S., Ata, K., Roby, G., et al. (2008) Lysis of Endogenously Infected $\mathrm{CD}^{+} \mathrm{T}$ Cell Blasts by rIL-2 Activated Autologous Natural Killer Cells from HIV-Infected Viremic Individuals. PLoS Pathogens, 4, e1000101. http://dx.doi.org/10.1371/journal.ppat.1000101

[13] Ward, J., Bonaparte, M., Sacks, J., Guterman, J., Fogli, M., Mavilio, D., et al. (2007) HIV Modulates the Expression of Ligands Important in Triggering Natural Killer Cell Cytotoxic Responses on Infected Primary T-Cell Blasts. Blood, 110, 1207-1214. http://dx.doi.org/10.1182/blood-2006-06-028175

[14] Moretta, A., Bottino, C., Vitale, M., Pende, D., Cantoni, C., Mingari, M.C., et al. (2001) Activating Receptors and Coreceptors Involved in Human Natural Killer Cell-Mediated Cytolysis. Annual Review of Immunology, 19, 197-223. http://dx.doi.org/10.1146/annurev.immunol.19.1.197

[15] Pende, D., Parolini, S., Pessino, A., Sivori, S., Augugliaro, R., Morelli, L., et al. (1999) Identification and Molecular Characterization of NKp30, a Novel Triggering Receptor Involved in Natural Cytotoxicity Mediated by Human Natural Killer Cells. The Journal of Experimental Medicine, 190, 1505-1516. http://dx.doi.org/10.1084/jem.190.10.1505

[16] Augugliaro, R., Parolini, S., Castriconi, R., Marcenaro, E., Cantoni, C., Nanni, M., et al. (2003) Selective Cross-Talk among Natural Cytotoxicity Receptors in Human Natural Killer Cells. European Journal of Immunology, 33, 12351241. http://dx.doi.org/10.1002/eji.200323896

[17] Wiemann, K., Mittrucker, H.W., Feger, U., Welte, S.A., Yokoyama, W.M., Spies, T., et al. (2005) Systemic NKG2D Down-Regulation Impairs NK and CD8 T Cell Responses in Vivo. The Journal of Immunology, 175, 720-729. http://dx.doi.org/10.4049/jimmunol.175.2.720

[18] Ferlazzo, G., Tsang, M.L., Moretta, L., Melioli, G., Steinman, R.M. and Munz, C. (2002) Human Dendritic Cells Activate Resting Natural Killer (NK) Cells and Are Recognized via the NKp30 Receptor by Activated NK Cells. The Journal of Experimental Medicine, 195, 343-351. http://dx.doi.org/10.1084/jem.20011149

[19] Mandelboim, O., Lieberman, N., Lev, M., Paul, L., Arnon, T.I., Bushkin, Y., et al. (2001) Recognition of Haemagglutinins on Virus-Infected Cells by NKp46 Activates Lysis by Human NK Cells. Nature, 409, 1055-1060. http://dx.doi.org/10.1038/35059110

[20] Vitale, M., Bottino, C., Sivori, S., Sanseverino, L., Castriconi, R., Marcenaro, E., et al. (1998) NKp44, a Novel Trig- 
gering Surface Molecule Specifically Expressed by Activated Natural Killer Cells, Is Involved in Non-Major Histocompatibility Complex-Restricted Tumor Cell Lysis. Journal of Experimental Medicine, 187, 2065-2072. http://dx.doi.org/10.1084/jem.187.12.2065

[21] Vieillard, V., Strominger, J.L. and Debre, P. (2005) NK Cytotoxicity against CD4 ${ }^{+}$T Cells during HIV-1 Infection: A gp41 Peptide Induces the Expression of an NKp44 Ligand. Proceedings of the National Academy of Sciences of the United States of America, 102, 10981-10986. http://dx.doi.org/10.1073/pnas.0504315102

[22] Borrego, F., Kabat, J., Kim, D.K., Lieto, L., Maasho, K., Pena, J., et al. (2002) Structure and Function of Major Histocompatibility Complex (MHC) Class I Specific Receptors Expressed on Human Natural Killer (NK) Cells. Molecular Immunology, 38, 637-660. http://dx.doi.org/10.1016/S0161-5890(01)00107-9

[23] Schim van der Loeff, M.F., Jaffar, S., Aveika, A.A., Sabally, S., Corrah, T., Harding, E., et al. (2002) Mortality of HIV-1, HIV-2 and HIV-1/HIV-2 Dually Infected Patients in a Clinic-Based Cohort in The Gambia. AIDS, 16, 17751783. http://dx.doi.org/10.1097/00002030-200209060-00010

[24] Bonaparte, M.I. and Barker, E. (2004) Killing of Human Immunodeficiency Virus-Infected Primary T-Cell Blasts by Autologous Natural Killer Cells Is Dependent on the Ability of the Virus to Alter the Expression of Major Histocompatibility Complex Class I Molecules. Blood, 104, 2087-2094. http://dx.doi.org/10.1182/blood-2004-02-0696

[25] Alter, G. and Altfeld, M. (2009) NK Cells in HIV-1 Infection: Evidence for Their Role in the Control of HIV-1 Infection. Journal of Internal Medicine, 265, 29-42. http://dx.doi.org/10.1111/j.1365-2796.2008.02045.X

[26] Cohen, G.B., Gandhi, R.T., Davis, D.M., Mandelboim, O., Chen, B.K., Strominger, J.L., et al. (1999) The Selective Downregulation of Class I Major Histocompatibility Complex Proteins by HIV-1 Protects HIV-Infected Cells from NK cells. Immunity, 10, 661-671. http://dx.doi.org/10.1016/S1074-7613(00)80065-5

[27] Moretta, L., Bottino, C., Pende, D., Castriconi, R., Mingari, M.C. and Moretta, A. (2006) Surface NK Receptors and Their Ligands on Tumor Cells. Seminars in Immunology, 18, 151-158.

[28] Mavilio, D., Benjamin, J., Daucher, M., Lombardo, G., Kottilil, S., Planta, M.A., et al. (2003) Natural Killer Cells in HIV-1 Infection: Dichotomous Effects of Viremia on Inhibitory and Activating Receptors and Their Functional Correlates. Proceedings of the National Academy of Sciences of the United States of America, 100, 15011-15016. http://dx.doi.org/10.1073/pnas.2336091100

[29] Valentin, A., Rosati, M., Patenaude, D.J., Hatzakis, A., Kostrikis, L.G., Lazanas, M., et al. (2002) Persistent HIV-1 Infection of Natural Killer Cells in Patients Receiving Highly Active Antiretroviral Therapy. Proceedings of the National Academy of Sciences of the United States of America, 99, 7015-7020. http://dx.doi.org/10.1073/pnas.102672999

[30] Kottilil, S., Shin, K., Planta, M., McLaughlin, M., Hallahan, C.W., Ghany, M., et al. (2004) Expression of Chemokine and Inhibitory Receptors on Natural Killer Cells: Effect of Immune Activation and HIV Viremia. The Journal of Infectious Diseases, 189, 1193-1198. http://dx.doi.org/10.1086/382090

[31] Yindom, L.M., Leligdowicz, A., Martin, M.P., Gao, X., Qi, Y., Zaman, S.M., et al. (2010) Influence of HLA Class I and HLA-KIR Compound Genotypes on HIV-2 Infection and Markers of Disease Progression in a Manjako Community in West Africa. Journal of Virology, 84, 8202-8208. http://dx.doi.org/10.1128/JVI.00116-10 